\title{
Editorial: Cidades e Sociabilidades
}

Em 1938, a fotógrafa suíça Hildegard Rosenthal, recém radicada no Brasil, registrou dentre suas diversas cenas urbanas a imagem intitulada "Vendedor de Frutas". Na fotografia percebemos os espaços ocupados por diferentes camadas sociais, o consumo a partir de um vendedor de rua, as roupas, a arquitetura e parte de um espaço de sociabilidade na primeira metade do século $X X$.

A imagem captada por Hildegard Rosenthal nos possibilita inferir sobre as relações em torno do vendedor de frutas. Transeuntes subindo a ladeira, um grupo de homens formais que conversam, os vendedores ambientados no cenário, um homem negro que saboreia seu pedaço de fruta e uma mulher que encara a fotógrafa antes de provar o alimento. Seriam essas pessoas assíduas na banca? Conhecidas pelo vendedor por seus nomes? Discutiriam elas sobre o tempo e as questões políticas enquanto compravam frutas? Ou eram apenas cidadãos anônimos da paisagem, que cotidianamente passavam por este lugar?

Como nos fragmentos escritos por Walter Benjamin em "Rua de mão única", onde os temas ganham significações e atenção para aquilo que é visto nos detalhes das fotografias, do cinema, do teatro, da música, dos anúncios, dos outdoors, dos selos, das cartas, dos cheiros, dos sabores, das paisagens e afins, é que talvez se saliente o punctum da imagem de Rosenthal.

$\mathrm{Na}$ contramão dos labirintos invisíveis e inventados entre os espaços citadinos, o número 5 da Revista Urbana apresenta algumas das contribuições recebidas para o dossiê Cidades e Sociabilidades. Entre a panóplia de estudos que tem interessado pesquisadores de diversas áreas do saber, compõe esta edição as pesquisas que abordam a interação social entre os indivíduos, em diferentes contextos que são significados e resinificados pelas experiências no espaço urbano, que se representam na vivência individual ou coletiva, nas ruas, nas festividades, nos espaços institucionais, nas associações, nos estabelecimentos comerciais, nas intrigas, entre outros lugares.

Com o texto de Adilson de Souza Moreira e Luiz Eduardo Fontoura Teixeira compreendemos as trocas socioculturais e simbólicas vivenciadas 
pelos indivíduos nos espaços de sociabilidade de Florianópolis, analisando as mudanças, permanências e atividades exercidas nas ruas do centro da cidade. Em outros cenários da mesma localidade, Sabrina Melo apresenta diferentes formas de sociabilidades nos cinemas, bares, cafés e teatros, destacando a vivência em espaços fechados. Carlos Alexandre Barros Trubiliano examina os embates sociais entre a elite e personagens urbanos nos espaços de modernização da cidade de Campo Grande, dando ênfase às questões da normatização e do controle social. Em Vitória, as sociabilidades são representadas pelos conflitos abordados no artigo de Fabíola Martins Bastos e Philipe Gomes Alves Pinheiro, apresentando-nos as ruas da capital na segunda metade do século XIX.

O significado das festas religiosas e a sua organização são discutidos por Mauro Dillmann Tavares, demonstrando como os cultos podem ser analisados a partir das práticas sociais em seu entorno. Sílvio Marcus de Souza Correa analisa por meio da imprensa alemã a particularidade das sociabilidades associativas na cidade portuária de Lüderitzbucht. Por fim, Thaís Troncon Rosa reflete sobre os espaços urbanos e a pobreza, oferecendo subsídios para investigações na área.

O presente número também é acompanhado de uma resenha sobre a história do turismo relacionada às férias e o tempo livre na Argentina, na qual a cidade balneária de Mar del Plata é analisada por Elisa Pastoriza, que demonstra historicamente as transformações sociais, políticas, culturais nesta sociabilidade veraniega. Na tradução de artigos, trouxemos um texto de Martin Jay, "The Senses in HistoryIn the Realm of the Senses: An Introduction", oferecendo subsídios para os pesquisadores no Brasil.

Agradecemos a todas pelas contribuições enviadas ao dossiê Cidades e Sociabilidades e aos pareceristas, que colaboraram com suas avaliações acuradas para a composição deste número. Na contramão dos saberes, convidamos os leitores a apreciarem os textos e desfrutarem das sociabilidades presentes nas particularidades da história dessas cidades.

Boa leitura, Carlos André de Moura Joana Carolina Schossler 